\title{
Perceptions of 'Hearing' People on Sign Language Learning
}

\author{
Bayu Ramadhani Fajri \\ Department of Electronic Engineering \\ Universitas Negeri Padang, Indoenesia \\ bayurf@unp.ac.id
}

\author{
Grahita Kusumastuti \\ Department of Special Education \\ Universitas Negeri Padang, Indonesia \\ grahita.kusuma@fip.unp.ac.id
}

\begin{abstract}
This study aims to determine public perception of sign language in Indonesia, especially towards BISINDO (sign Language of Indonesia). Sample of this research is one hundred people in Padang, which consists of workers and students. Data were collected through a survey. The instrument used is perception of sign language instrument which consists of people's understanding of sign language, the use of sign language by the community, the importance of sign language for the community, the needs of sign language learning media and sign language learning media that desired by community. The Data collected were analyzed quantitatively and qualitatively. Quantitative data is used to determine the percentage of society perception towards sign language in every aspect, and qualitative data is used to strengthen research results. Based on data analysis, it found that people still do not know sign language. On the other hand, people know that sign language needs to be learned to support communications between hearing people and deaf. So, it is expected a media that can help public to learn sign language without leave their daily routines and close with everyday life.
\end{abstract}

Keywords: deaf, sign language, social inclusion

\section{INTRODUCTION}

Since middle of 1990, the rights of individuals with special needs have been fought in Indonesia, especially in Yogyakarta and Solo, Central Java. Not only because these problems are one of the international problems that are also voiced in developed countries, but it is also recognized that individuals with special needs have the same rights as society in general. According to Law No. 19 of 2011, individuals with special needs, or better known as persons with disabilities, or disable (different ability people), or children with special needs are individuals who have physical, mental, intellectual or sensory limitations. The fulfillment of disability rights in Indonesia has become a commitment of the Indonesian government that has purpose to realize the independence and welfare of persons with disabilities. Government efforts in fulfilling disability rights are contained in the Convention on the Rights of Persons with Disabilities regulated in Law No. 19 of 2011.

One of the fulfillments of the rights for persons with disabilities that has been regulated in the law is regarding accessibility. Law No. 19 of 2011 article 9 clause 2 states that one form of accessibility for persons with disabilities can be the provision of forms of direct assistance and intermediaries, including guides, readers, and professional sign language translators, to facilitate accessibility to buildings and other facilities that are open to public.

Sign language is one aspect of accessibility for persons with disabilities, especially for the hearing impairment. Hearing impairment is an individual who has a permanent or temporary hearing loss at a mild to very severe level so that children cannot process language information through hearing, with or without loudspeakers [9]. Deaf or better known as hearing impairment, has a major obstacle in communication. People with hearing impairment need accessibility in communication, one of which is in the form of sign language.
Sign language is the language used for manual communication through body language or lip movements. Findings from research half a century ago shows that sign language is one of the languages in the world [6]. In this research it is known that humans become more flexible in speaking verbally and non-verbally. Through sign language, people with hearing impairment can communicate with their environment. In Indonesia, there are two signs of languages, that are the Indonesian Language Signaling System (SIBI) and Indonesian Sign Language (BISINDO). Hearing impairment is currently using BISINDO more in communication because BISINDO is a mother tongue and natural sign language of indigenous Indonesian culture so that it is easy to understand when used in their daily lives [7]. Therefore, sign language is important because it supports the fulfillment of the rights of persons with disabilities in terms of communication.

In fulfilling disability rights, especially people with hearing impairment, it is not only necessary to develop good accommodation for sign language. But support from the surrounding social environment. Sign language that has been developed for people with hearing impairment environment will not be useful if people generally do not care about sign language. A society that accepts individual differences will not occur if the business is conducted on only one party. Society is one of the factors in the realization of an inclusive society. Society acceptance of people with hearing impairment can support the occurrence of good social interaction in creating inclusive society. However, the lack of public awareness of sign language makes people with hearing impairment have obstacles in their social life [3]. The obstacle happens because of attitude (low self-esteem, pity, ignorance, prejudice, stereotypes) and other things related to difficulties in communication [2]. These obstacles not only make low social skills for people with hearing impairment, but also foster an inferiority complex, no enthusiasm for learning, and despair [5]. 
Based on this, it is necessary to know how people see sign language, in its usefulness and the desire to learn it. So, a research was conducted to measure people understanding towards sign language in their ability in communicate to people with hearing impairment. Also, research was also conducted on people perceptions in the desire to learn sign language. It is hoped that by answering two perceptions of the society towards the sign language, it can be seen that the society view towards sign language and the next step in developing media for learning sign language that is in accordance with the hope of the society. The implication of this research is that it is expected that sign language is easy to be learned by the surrounding society, without coercion, and facilitates communication between fellow humans, and supports a more inclusive society.

\section{METHOD}

This study uses a qualitative research approach by a survey. The Sample in this study was one hundred people consisting of two groups of people, namely workers and students in Padang. The instruments that used in this study was the perception of sign languages instrument which includes five aspects, namely: people's understanding of sign language, the use of sign language by the community, the importance of sign language for the community, the needs of sign language learning media and sign language learning media that desired by the society.

The data collected were analyzed quantitatively and qualitatively. Quantitative data obtained from the fifth aspect of the instrument. Qualitative data obtained from the reason and advice about sign language learning. The quantitative data strengthened the qualitative data, then interpreted to note the conclusions and implications of this research.

\section{RESULT}

Based on the results of society perception data collection on sign language, the results are as follows:

\section{A. Recognizing Sign Language}

The level of recognizing sign language by the society is measured through indicator question "Do you know sign language?". The results of the data on the level of recognition of sign language by workers and students can be seen in Table 1 and Table 2. While the data on the level of recognizing sign language by the society can be seen in Figure 1.

Based on Tables 1 and 2 and Figure 1, it is known that out of one hundred respondents, $64 \%$ of respondents do not know sign language well. $64 \%$ respondents who do not know sign language well, more groups of students who do not know sign language than those from groups of workers $($ students $=68 \%$, workers $=64 \%$ )

\section{B. Skill in Using Sign Language by the Society}

Skill in using sign language by the society is measured through indicator question "Can you use sign language? The results the skill in using sign language data by the society can be seen in Figure 2 .

It is known that out of one hundred respondents, $89 \%$ of respondents do not know how to use sign language well. $89 \%$ respondents who do not know how to use sign language well, more groups of students who do not know how to use sign language than those from groups of workers (students $=94 \%$, workers $=86 \%$ ).

Table 1

Level of Recognizing Sign Language by Workers

\begin{tabular}{|c|c|c|}
\hline Criteria & N & \% \\
\hline SDK & 2 & 4 \\
\hline DK & 8 & 16 \\
\hline F & 12 & 44 \\
\hline K & 16 & 32 \\
\hline SK & 2 & 4 \\
\hline Total & $\mathbf{5 0}$ & $\mathbf{1 0 0}$ \\
\hline
\end{tabular}

Table 2

Level of Recognizing Sign Language by Students

\begin{tabular}{|c|c|c|}
\hline Criteria & $\mathbf{N}$ & \% \\
\hline SDK & 2 & 4 \\
\hline DK & 6 & 12 \\
\hline F & 26 & 52 \\
\hline K & 12 & 24 \\
\hline SK & 4 & 8 \\
\hline Note & $\mathbf{5 0}$ & $\mathbf{1 0 0}$ \\
\hline
\end{tabular}

Note:

SDK : Strongly don't know

DK : Don't know

F : Fairly

K : Know

SK : Strongly know

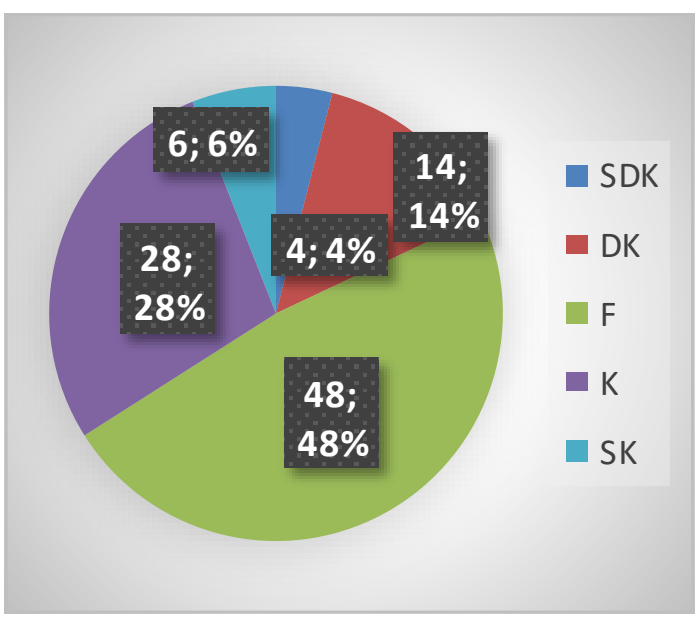

Figure 1

Level of recognizing sign language by society

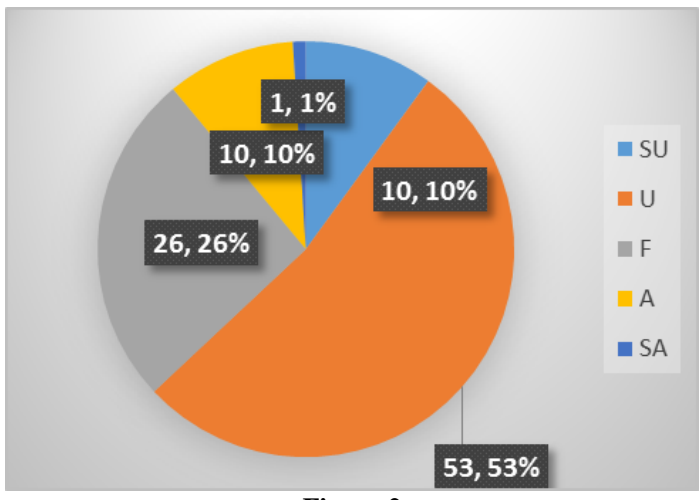

Figure 2

Skill in Using Sign Language by the Society

\section{The Importance of Sign Language}

The importance of sign language from society's view is measured through indicator question is sign language important to communicate between hearing 
people and deaf people? The importance of sign language from society's view data can be seen in Figure 3.

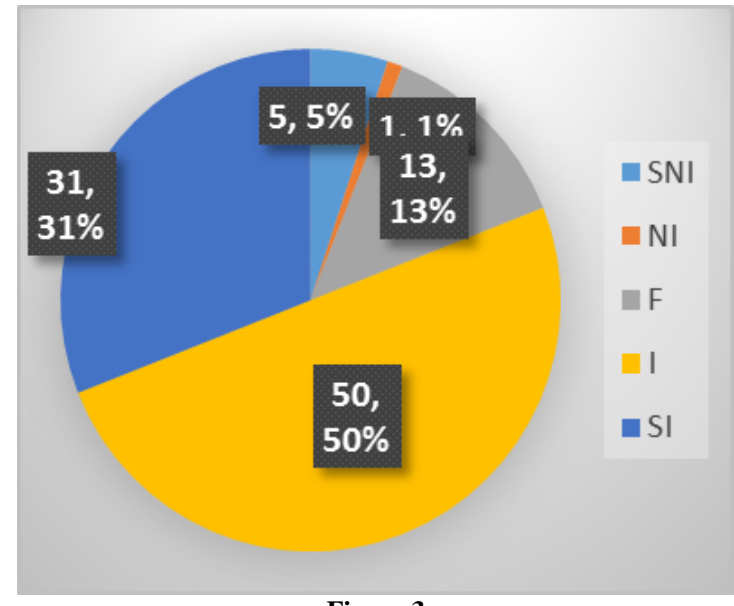

Figure 3

The Importance of Sign Language from Society's View

It is known that out of one hundred respondents, $94 \%$ of respondents state that sign language is important to communicate between hearing people and deaf people. $94 \%$ respondents who state that sign language is important to communicate between hearing people and deaf people, more groups of students who state that sign language is important to communicate than those from groups of workers (students $=96 \%$, workers $=92 \%$ ).

\section{The Need of Sign Language Learning for Society}

The need of sign language learning for society is measured through indicator question: Do you need any media to learn sign language? The results of the need of sign language learning for society data can be seen in Figure 4.

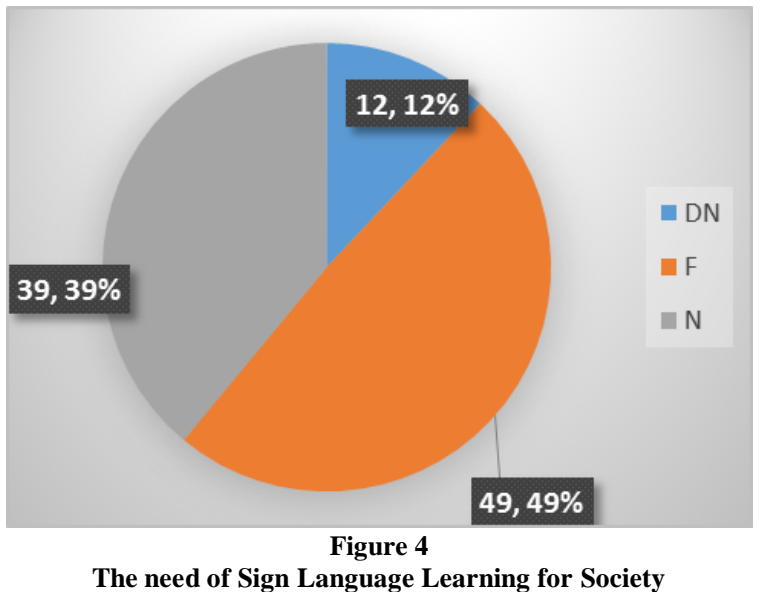

It is known that out of one hundred respondents, $88 \%$ of respondents state that society need sign language learning. $88 \%$ respondents who state that society need sign language learning, more groups of students who state that society need sign language learning than those from groups of workers $($ students $=92 \%$, workers $=84 \%$ ).

\section{E. Sign Language Learning Media Desired by the Society}

Sign language learning media desired by the society is measured through indicator question "What kind media that you desired to learn sign language?". The results of sign language learning media desired by society data can be seen in Figure 5.

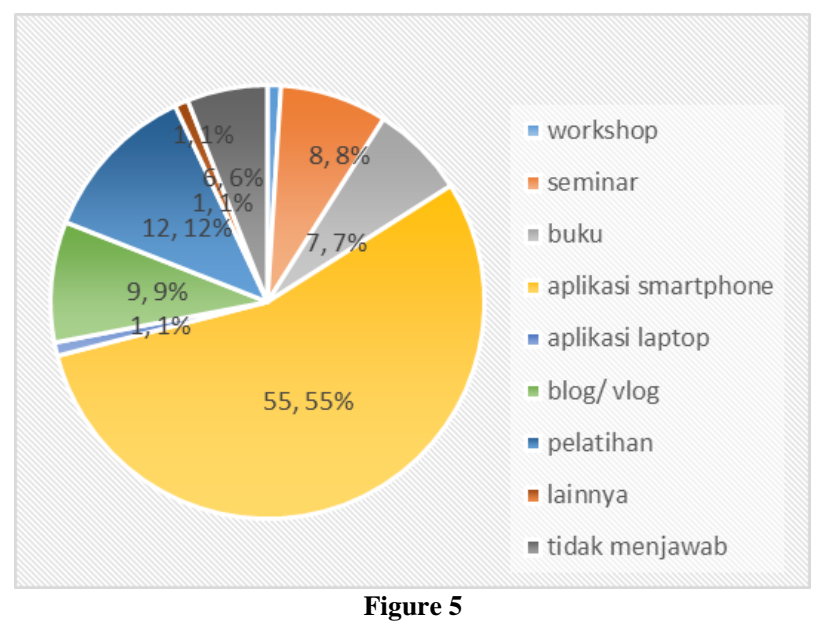

Sign Language Learning Media Desired by Society

It is known that out of one hundred respondents, $55 \%$ respondents stated that the society needs media in the form of applications on smartphones to learn sign language. $55 \%$ of respondents who stated that the society needs media in the form of applications on smartphones to learn sign language, more student groups wanted to learn in smartphone applications than from groups of workers (students $=56 \%$, workers $=54 \%$ ).

\section{DISCUSSION}

Based on the results of data analysis, it is known that people do not know sign language well, but have the desire to learn sign language and feel that sign language is important for the communication between normal people and people with hearing impairment. Also, the public wants the media availability that can help people learn sign language in the form of smartphone applications.

Smartphone applications are technological developments that are in great demand by the public. This is intended to make smartphone applications a media that people want in learning sign language. This is related to the role of smartphone applications as one of information technology that can be an important facility in social inclusion for the society and people with special needs [4].

Through the smartphone application that the society wants, it is expected that communication between normal people and people with hearing impairment can be well implemented. This is because normal people need to understand that the effects of good communication with people with hearing impairment can build good relationships [1]. This is because, if the normal people understand how to communicate with people, the feeling of being excluded from the people can be reduced, so that it is no longer become obstacle to people [8].

Basically, people have the desire to learn sign language, and they feel that sign language is important to implement communication between people. This is confirmed by the results of qualitative analysis which indicates that people who are not familiar with sign language feel that sign language is important because of these following reasons: 
1. Sign language is a communication for people with hearing impairment.

2. As a skill to be able to communicate with people with hearing impairment.

3. Even though the hearing and speech of people is difficult, they are also human and live in society

4. Can help people who have hearing impairment to increase their confidence.

Based on the results of the discussion, the implications of this research are the development of a sign language learning media adjusted to the hope of the society. This research will be continued by designing interesting media on smartphone applications to make people easier to learn sign language.

\section{CONCLUSION}

Based on the results of the discussion, it can be concluded that the community, both from the young generation (students) to the old generation (the workers) do not know sign language well. However, people understand the use of sign language and desired to learn it. However, people haven't got the sign language learning media which fit with the daily activity. The society wants a sign language learning media that can help people learn sign language effectively, namely through a smartphone application that is easily accessible to the public.

\section{REFERENCES}

[1] Hankins, Rebecca Carol. (2015). Social Interacation between deaf and hearing people. Oxford: The University of Mississippi.

[2] Ladd, P. (2005). Deafhood: A concept stressing possibilities, not deficits. Scandinavian Journal of Public Health, 33, 12 17.

[3] Lee, C., \& Pott, S. A. (2018). University students' attitudes towards deaf people: educational implications for the future educational implications for the future. Deafness \& Education International, 2(2), 1-20.

[4] Manzoor \& Vimarlund. (2018). Digital technologies for social inclusion of individuals with disabilities. Health and Technology, 8, 377-390.

[5] Munoz-Baell, I., \& Ruize, M. T. (2000). Empowering the deaf. Let the deaf be deaf. Journal of Epidemiology \& Community Health, 54, 40-44.

[6] Perlmutter, D. M. (1991). What is Sign Language. Washington, DC: Linguistic Society of America.

[7] Riadi, A., \& Aditia, P. (2017). Buku Ilustrasi Bahasa Isyarat Indonesia (BISINDO) bagi Anak Tunarungu. In eProceeding of Art \& Design (pp. 799-804).

[8] Scheetz, N. A. (2004). Psychosocial aspects of deafness / Nanci A. Scheetz. Boston, MA : Pearson/A \& B

[9] Smith, J. David. 2006. Inklusi, Sekolah Ramah Anak. Bandung: Nuansa. 